\title{
PENGARUH PELAYANAN KESEHATAN IBU DAN ANAK TERHADAP PENINGKATAN KESEHATAN MASYARAKAT (Studi pada Pusat Kesehatan Masyarakat Kibin Kecamatan Kibin Kabupaten Serang)
}

\author{
Rosilawati \\ Program Studi Ilmu Administrasi Negara STIA Maulana Yusuf Banten \\ Jl. Trip K. Jamaksari No. 44 Cinanggung Serang \\ Email: hjrosilawati@gmail.com
}

\section{Ringkasan}

Penelitian ini bertujuan untuk mengetahui apakah ada pengaruh yang signifikan antara pelayanan Kesehatan Ibu dan Anak terhadap peningkatan kesehatann masyarakat. Penelitian ini bersifat kuantitatif, adapun populasi dan sampel yang diambil sebanyak 78 orang responden dengan pengambilan sampel secara didsproportionate stratified random. Data instrumen penelitian menggunakan tiga jenis alat, yaitu kuesioner dengan menggunakan model skala Likers. Kuesioner disusun dengan konstruksi berbagai teori analisis data yang dilakukan pada tingkat $95 \%$ hasilnya adalah secara signifikan sepanjang hipotesis yang ada. Sehingga hasil penelitian ini memberi tahu bahwa variabel pelayanan Kesehatan Ibu dan Anak dapat mempengaruhi tingkat kesehatan masyarakat (Studi pada Pusat Kesehatan Masyarakat Kecamatan Kibin Kabupaten Serang..

Kata Kunci : Pelayanan Kesehatan Ibu dan Anak, Kesehatan Masyarakat

\begin{abstract}
This study aims to determine whether there is a significant influence between maternal and child health services on improving community health. This research is quantitative, as for the population and samples taken as many as 78 respondents with a randomly stratified random sampling. Instrument research data uses three types of tools, namely questionnaires using the Likers scale model. The questionnaire was prepared with the construction of various data analysis theories carried out at the level of 95\%. The results were significant as long as the hypothesis existed. So that the results of this study tell that the variables of maternal and child health services can influence the level of public health.
\end{abstract}

Keywords: Maternal and Child Health Services, Public Health

\section{PENDAHULUAN}

Sejalan dengan reformasi dibidang kesehatan melalui paradigma sehat, pelayanan kesehatan di rumah sakit maupun di puskesmas lebih difokuskan pada upaya promosi kesehatan (promotif) dan pencegahan (preventif) dengan tidak mengabaikan upaya kuratif-rehabilitatif. Selain itu, pelayanan kesehatan khususnya di puskesmas bukan hanya kepada individu (pasien), tetapi juga keluarga dan masyarakat, sehingga pelayanan kesehatan yang dilakukan merupakan pelayanan kesehatan yang paripurna (komprehensif dan holistik).

Pusat Kesehatan Masyarakat (PUSKESMAS) sebagai Unit Pelaksana Teknis Dinas merupakan ujung tombak dalam pelayanan kesehatan yang pada dasarnya melaksanakan dua jenis pelayanan; (1) pelayanan kesehatan dan (2) pelayanan administrasi.

Pelayanan kesehatan yang diberikan adalah pelayanan medik, pelayanan penunjang medik, rehabilitasi medik dan pelayanan keperawatan, termasuk didalamnya 
pelayanan Kesehatan Ibu dan Anak. Dengan bergesernya orientasi pembangunan kesehatan, mendorong agar puskesmas melakukan perubahan visi, misi dan strategi dalam melakukan pelayanan kesehatan kepada masyarakat. Visi merupakan impian atau cita-cita yang ingin diwujudkan, yang dapat mengantisipasi perubahan yang sedang dan akan terjadi. Apabila suatu organisasi tidak memiliki visi maka perubahan lingkungan yang tidak diduga sebelumnya sering dirasakan sebagai suatu musibah. Sedangkan misi dan strategi dibuat dalam rangka merealisasikan visi yang telah ditetapkan.

Dalam rangka pemerataan pelayanan kesehatan kepada masyarakat, maka perlu adanya pengelolaan bidang kesehatan secara efektif dan efisien. Oleh karena itulah Menteri Kesehatan Republik Indonesia mengeluarkan Surat Keputusan Nomor : 99 / Menkes / SK / III / 1982 tentang Sistem Kesehatan Nasional. Pemikiran dasar Sistem Kesehatan Nasional pada hakekatnya menentukan arah, tujuan dan dasar-dasar pembangunan kesehatan sebagai suatu kesatuan yang menyeluruh, terpadu, dan berkesinambungan sebagai bagian dari pembangunan nasional.

Sebagai wujud nyata untuk memberikan pemerataan pelayanan kesehatan kepada masyarakat, telah dibangun Pusat Kesehatan Masyarakat (PUSKESMAS) ditiap-tiap Kecamatan. Pelayanan kesehatan melalui puskesmas merupakan upaya yang menyeluruh dan terpadu, upaya ini meliputi peningkatan, pencegahan, dan penyembuhan penyakit, serta meminimalisir warga masyarakat yang mengidap gizi buruk. Upaya pelayanan kesehatan ditiap-tiap Puskesmas dalam rangka melaksanakan program yang meliputi kesejahteraan Ibu dan Anak (KIA), Keluarga Berencana (KB), Diare, Imunisasi serta gizi.

Program-program ini diwujudkan melalui berbagai kegiatan pekerjaan kesehatan mulai dari pencatatan data kesehatan masyarakat termasuk data kesehatan ibu dan anak. Program ini untuk meningkatkan kualitas sumber daya manusia yang sehat, memiliki jiwa yang kuat dan sejahtera. Untuk mewujudkan manusia yang sehat dan sejahtera dimaksud, sedini mungkin harus memperhatikan kesehatan ibu dan anak.

Puskesmas Kibin dalam melaksanakan tugasnya mencakup Kecamatan Kibin, salah satunya adalah memberikan pelayanan Kesehatan Ibu dan Anak (KIA). Khususnya di wilayah Puskesmas Kibin masih terdapat ibu dan anak yang tidak mau melaksanaan pemeriksaan kesehatan baik ke Posyandu maupun ke Puskesmas setempat, hal ini disebabkan oleh kemampuan ekonomi dan pemahaman terhadap pentingnya kesehatan masih sangat kurang.

Pelayanan dikemukakan oleh H.A.S. Moenir merupakan kunci keberhasilan dalam berbagai usaha atau kegiatan yang bersifat jasa, 2008:vii). Selanjutnya Ratminto \& Atik Septi Winarsih, dalam Gronroos (1990:27), mengemukakan pelayanan adalah suatu aktivitas atau serangkaian aktivitas yang bersifat tidak kasat mata (tidak dapat diraba) yang terjadi sebagai akibat adanya interaksi antara konsumen dengan pegawai atau hal-hal yang disediakan oleh instansi/organisasi pemberi pelayanan yang dimaksudkan untuk memecahkan permasalahan konsumen/ pelanggan dalam hal ini masyarakat",(2008:2).

Sebagaimana diketahui bahwa dalam penelitian ini penulis membahas tentang pelayanan publik karena pelayanan yang disediakan oleh Puskesmas adalah pelayanan kepada masyarakat. Berdasarkan Undangundang nomor 25 tahun 2009 tentang Pelayanan Publik mengemukakan pengertian Pelayanan Publik sebagai berikut: "Pelayanan Publik adalah segala kegiatan pelayanan yang dilaksanakan oleh penyelenggara pelayanan publik sebagai upaya pemenuhan kebutuhan penerima pelayanan maupun pelaksanaan ketentuan peraturan perundang-undangan".

Untuk dapat memberikan pelayanan yang memuaskan kepada masyarakat termasuk pelayanan Kesehatan Ibu dan anak, harus memperhatikan azas-azas pelayanan 
sebagaimana dikemukakan oleh Ratminto \& Atik Septi Winarsih) (2008:19-20)., sebagai berikut: 1) Transparan; 2) Akuntabilitas; 3) Kondisional; 4) Partisipatif; 5) Kesamaan Hak; 5) Keseimbangan Hak dan Kewajiban. Berdasarkan seluruh pendapat para ahli tersebut di atas bahwa dalam menanggulangi Kesehatan Ibu dan Anak (KIA) diperlukan pelayanan yang optimal dengan memperhatikan azas pelayanan yang dikemukakan oleh Ratminto \& Atik Septi Winarsih.

Delapan unsur kemampuan pelayanan berdasarkan Kementrian Pendayagunaan Aparatur Negara yang tertuang dalam Surat Edaran Nomor : 81/1993, perihal : Kualitas Pelayanan, meliputi : (1) kesederhanaan; (2) kejelasan; (3) keamanan; (4) keterbukaan; (5) efisien; (6) ekonomis; (7) keadilan, dan (8) ketepatan waktu. Secara garis besarnya pelayanan yang diberikan mengandung unsur pokok, yaitu : kecepatan, kebenaran, keramahan, kenyamanan. Keempat komponen itu merupakan satu kesatuan pelayanan terintegrasi, artinya pelayanan menjadi tidak prima kalau ada komponen yang kurang. Artinya, di dalam melayani pemberian rekomendasi, petugas harus bersikap ramah, cepat dengan suasana yang nyaman pula, tetapi ternyata hasil kerjanya menunjukan banyak kesalahan (tidak benar) jadi tidak ada gunanya. Hal semacam itu tentunya akan sangat mengecewakan publik yang dilayani.

Pelayanan dalam organisasi/instansi pemerintah biasa diterjemahkan sebagai suatu upaya pelayanan yang meliputi : Pelayanan Fisik, erat kaitannya dengan benda tidak bergerak dan tampak serta dapat diraba oleh public, seperti : Interior bangunan (penataan ruangan dilihat dari aspek kenyamanan, kebersihan dan keindahan), Eksterior bangunan (fasilitas parker harus memadai kapasitasnya dan tariff yang diberikan secara cuma-cuma).

Pelayanan prima, suatu sikap atau cara petugas dalam melayani public secara memuaskan. Sasarannya tiada lain adalah : memuaskan public, meningkatkan loyalitas public, meningkatkan pemberian pelayanan jasa, meningkatkan pendapatan/PAD.

Produk yang ditawarkan, merupakan suatu yang tidak nyata (intangible). Produk tersebut adalah jasa yang dikemas secara bersama-sama untuk menyajikan beberapa manfaat kepada public. Sebagian besar publik cenderung untuk memilih instansi yang memberikan pelayanan yang lengkap sebagai mitra mereka dalam

melaksanakan usahanya, termasuk juga : prosedur pelayanan yang sederhana dan tidak rumit, kecepatan dalam memperoleh informasi, melalui brosur, iklan yang mudah dimengerti, keamanan yang terjamin.

Pada dasarnya semua bentuk pelayanan yang diberikan senantiasa harus diorientasikan pada kepuasan public yang dilayani, sehingga dari rasa puas itu akan menimbulkan dukungan yang baik dari public terhadap eksistensi organisasi yang memberikan pelayanan sekaligus dapat memberikan nilai tambah bagi organisasi.

Depdagri dan Otonomi Daerah dan Departemen Keuangan ( 2000 : 51 - 57 ) menguraikan prilaku yang mengarah kepada pelayanan prima, adalah : 1) Self Esteem (harga diri): Pelayanan bukan berarti patuh, Keteladananan dari Top Pimpinan, Positive approach kepada pegawai, prilaku Pimpinan, tempatkan orang yang positif sesuai dengan bidang pekerjaannya, buatlah tugas penyedia pelayanan menarik, kesuksesan hari ini tidak menjamin kesuksesan hari esok. 2) Exeed expectations (melampoi yang diharapkan). 3) Recovery (pembenahan). 4) Vision (pandangan kedepan) 5) Improve (peningkatan).6) Care (perhatian).

Disamping itu menurut Undang Undang nomor: 25 tahun 2009, pasal (4), mengemukakan bahwa terdapat beberapa asas pelayanan publik, sebagai berikut: kepentingan umum; kepastian hukum; kesamaan hak; keseimbangan hak dan kewajiban; keprofesionalan; partisipatif; persamaan perlakuan/tidak diskriminatif; keterbukaan; akuntabilitas; fasilitas dan perlakuan khusus bagi kelompok rentan; 
ketepatan waktu, kecepatan, kemudahan dan keterjangkauan.

Keseluruhan azas pelayanan di atas, dimaksudkan untuk melayani Kesehatan Ibu dan Anak didalamnya pemeriksaan kehamilan, komplikasi kebidanan, Pertolongan Persalinan oleh Tenaga Kesehatan, nifas, Pelayanan Neonatus dengan Komplikasi, Kunjungan Bayi, Imunisasi Bayi, Pelayanan Anak Balita, Pemberian Makanan Pendamping ASI, Perawatan Balita Gizi Buruk, dan Penjaringan Kesehatan Anak Sekolah Dasar, sehingga masyarakat dapat meningkatkan kesehatannya.

Sebelum penulis mengemukakan tentang definisi kesehatan mayarakat terlebih dahulu penulis mengemukakan pengertian Sehat menurut Undang Undang Pokok Kesehatan No. 9 tahun 1960, Bab I Pasal 2 adalah sebagai berikut:

"Sehat adalah keadaan yang meliputi kesehatan badan (jasmani), rohani (mental), dan sosial, serta bukan hanya keadaan bebas dari penyakit, cacat, dan kelemahan".

Kemudian pengertian Kesehatan sebagaimana tercantum dalam Undang- Undang N0. 23 Tahun 1992, bahwa kesehatan mencakup 4 aspek, yakni: fisik (badan), mental (jiwa), sosial, dan ekonomi.

Pengertian masyarakat sebagaimana dikemukakan oleh Soerjono Soekamto dalam bukunya Sosiologi Suatu Pengantar, sebagai berikut: "Masyarakat adalah sekelompok individu yang mempunyai hubungan, memiliki kepentingan bersama, dan memiliki budaya" (2009:150). Selanjutnya penulis mengemukakan pengertian kesehatan masyarakat yang disampaikan oleh Winslow (1920) yang dikutip oleh Soekidjo Notoatmodjo (2003:10), mengemukakan sebagai berikut: "Kesehatan Masyarakat (public health) adalah ilmu dan seni mencegah penyakit, memperpanjang hidup, dan meningkatkan kesehatan, melalui usahausaha pengorganisasian masyarakat untuk perbaikan (1). Sanitasi Lingkungan; (2). Pemberantasan Penyakit menular, (3).
Pendidikan untuk kebersihan perorangan, (4). Pengorganisasian pelayanan-pelayanan medis dan perawatan untuk diagnosis dini dan pengobatan, (5). Pengembangan rekayasa sosial untuk menjamin setiap orang terpenuhi kebutuhan hidup yang layak dalam memelihara kesehatannya.

Selanjutnya menurut Ikatan Dokter Amerika (1948) yang penulis sadur dari http://environmentalsanitation.wordpress.com /category/pengertian-kesehatan-masyarakat/, December 27, 2008, Archive for the 'Pengertian Kesehatan Masyarakat' Category, mengemukakan pengertian kesehatan masyarakat adalah sebagai berikut: "Kesehatan masyarakat adalah ilmu dan seni memelihara, melindungi dan meningkatkan kesehatan masyarakat melalui usaha-usaha pengorganisasian masyarakat.

Tolok ukur kesehatan masyarakat berdasarkan upaya-upaya yang dikatagorikan sebagai seni atau penerapan ilmu kesehatan masyarakat sebagaimana dikemukakan oleh Soekidjo Notoatmodjo (2003:12), sebagai berikut: 1) Pembinaan Gizi Masyarakat; 2) Pengawasan Sanitasi tempat-tempat umum; 3) Pemberantasan penyakit, baik menular maupun tidak menular; 4 4) Perbaikan sanitasi lingkungan; 5) Perbaikan lingkungan pemukiman;

6) Pemberantasan vektor; 7) Pendidikan (penyuluhan) Kesehatan Masyarakat; 8) Pelayanan Kesehatan Ibu dan anak; 9) Pengawasan obat dan minuman; 10) Pembinaan peran serta masyarakat.

Pelayanan Kesehatan Ibu dan Anak merupakan salah satu tujuan Pembangunan Milanium atau Millanium Devalopment Goals (MDGs), dengan sasaran program pembangunan kesehatan diantaranya (1). Menurunkan Angka Kematian Ibu (AKI) 3/4 diantara tahun 1900-2015, dan (2). Menurunkan Angka Kematian Bayi (AKB) 2/3 diantara tahun 1900-2015, dengan target sebagai berikut: 1) Menurunkan Angka Kematian Ibu menjadi 125/100.000 angka kelahiran hidup; 2) Menurunkan Angka Kematian Neonatal menjadi 15/1.000 
kelhiran hidup; 3) Menurunkan anemia gizi besi menjadi 20\%; 4) Menurunkan angka kehamilan yang tidak diingini dari $17 \%$, menjadi $3 \%$.

Untuk mencapai target tersebut terdapat beberapa strategi yang dilakukan dalam upaya menurunkan Angka Kematian ibu dan Menurunkan Angka Kematian Bayi, diantaranya adalah: 1) Menggerakkan dan memberdayakan masyarakat untuk hidup sehat; 2) Meningkatkan akses masyarakat terhadap pelayanan kesehatan yang berkualitas; 3) Meningkatkan system survailance, monitoring dan informasi kesehatan; 4) Meningkatkan pembiayaan kesehatan.

Mengingat Pusat Kesehatan Masyarakat merupakan pelaksana teknis dalam pelayanan masyarakat bidang kesehatan, karenanya harus memperhatikan asas-asas pelayanan serta dapat memberikan pelayanan yang prima kepada masyarakat khususnya bidang kesehatan.

Dari pemaparan yang disajikan penulis ingin mngetahui seberapa besar pengaruh pelayanan Kesehatan Ibu dan Anak terhadap peningkatan kesehatan masyarakat. Adapun hipotesis yang diajukan adalah :

$\mathrm{Ha}>0$ : Pelayanan berpengaruh positif dan signifikan terhadap peningkatan kesehatan masyarakat.

Ho $\leq 0$ : Pelayanan tidak berpengaruh positif dan signifikan terhadap peningkatan kesehatan masyarakat.

\section{METODE PENELITIAN}

Penulisan ini menggunakan jenis penulisan deskriptif kausal dengan pendekatan kuantitatif.

Teknik pengumpulan data yang digunakan oleh penulis yaitu : Studi Kepustakaan (Library Research), Penulisan Lapangan (Field Reserach): Interview, Observasi non-partisipatif, Angket Tertutup.
Teknik sampling yang digunakan dalam penulisan ini adalah didsproportionate stratified random. Populasi ditetapkan sebanyak 104 orang, sedangkan sampel yang akan diambil sebanyak 78 responden.

\section{Uji Analisa Data}

Uji Validitas, untuk menguji validitas instrumen menggunakan program "Microsoft Exel" syarat minimum untk dianggap valid bila $r=0,3$. Dimana dalam uji validitas ini dilakukan suatu perbandingan antara $r$ hitung dan $r$ tabel. Adapun rumus $r$ hitung adalah dengan menggunakan rumus product moment

$$
r_{x y}=\frac{n \Sigma X Y-(\Sigma X)(\Sigma Y)}{\sqrt{\left\{n \Sigma X^{2}-(\Sigma X)^{2} \int_{n} \sum Y^{2}-(\Sigma Y)^{2}\right\}}}
$$

Dimana : $\quad r=$ korelasi product moment $\mathrm{n}=$ jumlah responden

$\mathrm{x}=$ skor butir pertanyaan $\mathrm{y}=$ skor total

\section{Uji Reliabilitas}

Uji Reliabilitas pengujian reabilitas instrumen menggunakan insternal consistency dengan teknik belah dua (spilt half), dari Spearmen Brown yaitu :

$$
r_{j}=\frac{2 \times r_{x y}}{\left(1+r_{x y}\right)}
$$

Dimana : $\quad$ ri $=$ Reliabilitas instrumen antara jawaban kuesioner

$$
\text { Rxy }=\text { Koefisien korelasi }
$$

\section{Teknik Pengolahan dan Analisa Data}

Kegiatan yang dilakukan dalam mendisain angket penulisan/ menenetukan skala pengukuran terhadap variabel-variebel yang terlibat dalam penulisan menggunkana skala likert mempunyai tingkatan dari sangat positif sampai dengan negatif. 


\section{Tabel 1}

Tabel Skor Kriteria Jawaban

\begin{tabular}{lc}
\hline \multicolumn{1}{c}{ Pertanyaan } & Skor \\
\hline Sangat Setuju (SS) & 5 \\
Setuju (S) & 4 \\
Cukup Setuju (CS) & 3 \\
Tidak Setuju (TS) & 2 \\
Sangat Tidak Setuju (STS) & 1
\end{tabular}

Penulis menganalisis data dan menginterpretasikan faktor-faktor yang diperoleh dalam penulisan dan menyesuaikan dengan teori yang mendukung penulisan secara kuantitatif untuk menghitung tingkat pelayanan Kesehatan Ibu dan Anak, penulis akan mengumpulkan data yang diperoleh melalui kuesioner kemudian dianalisis.

\section{Analisis Koefisien Korelasi}

Untuk menganalisis data, penulis melakukan analisis secara kuantitatif dengan menggunakan metode perhitungan statistik non parametrik diantaranya sebagai berikut :

Tabel: 2

Kriteria Penilaian

\begin{tabular}{ccc}
\hline KIA & Interval & Kesmas \\
Keterangan & & Keterangan \\
Sangat Tidak Tepat & $1,00-1,79$ & Rendah \\
Kurang Tepat & $1,80-2,59$ & Kurang \\
Cukup Tepat & $2,60-3,39$ & Cukup \\
Tepat & $3,40-4,19$ & Tinggi \\
Sangat Tepat & $4,20-5,00$ & Sangat Tinggi
\end{tabular}

Analisis data dengan menggunakan perhitungan korelasi dari Rank Spearman (rs). Korelasi Rank Spearman sebagai berikut :

$$
r_{s}=\frac{\sum X^{2}+\sum Y^{2}-\sum d i^{2}}{2 \sqrt{\left(\sum X^{2}\right)\left(\sum Y^{2}\right)}}
$$

Dengan ketentuan sebagai berikut :

$$
\begin{aligned}
& \sum x^{2}=\frac{n\left(n^{2}-1\right)}{12}-\sum T x \\
& T_{x}=\frac{t^{3}-t}{12} \\
& \sum y^{2}=\frac{n\left(n^{2}-1\right)}{12}-\sum T y \\
& T_{y}=\frac{t^{3}-t}{12}
\end{aligned}
$$

Dimana : $\quad \mathrm{di}^{2} \quad=$ selisih antara variabel $\mathrm{X}$ dan variabel $\mathrm{Y}$ 


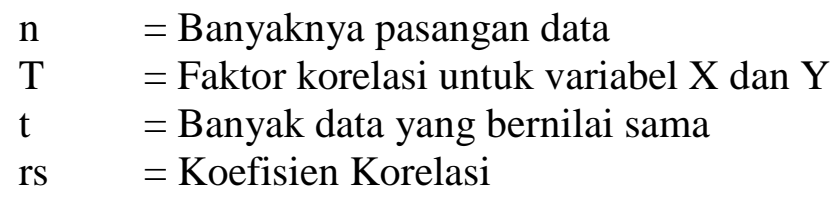

Digunakan jika didalam observasi tersebut tidak terdapat angka yang sama atau kembar, maka menggunakan rumus:

$$
r_{s}=1-\frac{6 \sum d i^{2}}{n\left(n^{2}-1\right)}
$$

Harga rs selalu bergerak dari -1 sampai +1 . bila rs $=+1$ berarti hubungan antara variabel $\mathrm{X}$ dan variabel $Y$ sangat kuat atau cukup kuat dan mempunyai pengaruh yang positif. Sedangkan jika rs $=-1$ berarti pengaruh antara variabel $\mathrm{X}$ dan variabel $\mathrm{Y}$ sangat kuat atau cukup kuat dan mempunyai pengaruh yang negatif.

Untuk mengetahui seberapa besar derajat hubungan antara variabel $\mathrm{X}$ dan variabel $\mathrm{Y}$, diperlukan taksiran yang dijelaskan dengan menggunakan batasan-batasan sebagai berikut :

Tabel 3

Koefisien Korelasi

\begin{tabular}{cc}
\hline Interval Koefisien & Tingkat Hubungan \\
\hline $0,00-0,199$ & Sangat Rendah \\
$0,20-0,399$ & Rendah \\
$0,40-0,599$ & Cukup Kuat \\
$0,60-0,799$ & Kuat \\
$0,80-1,000$ & Sangat Kuat \\
\hline
\end{tabular}

Sugiyono (2003).

\section{Menentukan taraf signifikan}

Untuk masalah ini, penulis mengambil interval keyakinan sebesar $95 \%$ sehingga tingkat kesalahan $(\alpha)$ sebesar 5\% dan derajat kebebasan ( $\mathrm{dk}$ ) dengan rumus :

$\mathrm{dk}=\mathrm{n}-2$

Menentukan $\mathrm{t}$ hitung dengan rumus :

$$
t=r_{s} \sqrt{\frac{n-2}{1-r_{s}^{2}}}
$$

Dimana : $r s=$ Koefisien Korelasi Spearman

$$
\begin{aligned}
& \mathrm{n}=\text { Banyaknya Sampel } \\
& \mathrm{t}=\text { Distribusi Student }
\end{aligned}
$$

Membandingkan $\mathrm{t}$ tabel terhadap $\mathrm{t}$ hitung dengan kriteria : $\mathrm{t}$ hitung $\leq \mathrm{t}$ tabel maka Ho diterima dan Ha ditolak dan $\mathrm{t}$ hitung $>\mathrm{t}$ tabel maka Ho ditolak dan Ha diterima.

\section{HASIL PENELITIAN DAN PEMBAHASAN \\ Analisis Seluruh Item Pertanyaan Variabel Bebas (Pelayanan Kesehatan Ibu Dan Anak)}

Untuk mengetahui bagaimana pelaksanaan Pelayanan Kesehatan Ibu Anak secara keseluruhan dapat dihitung secara keseluruhan dengan melakukan perkalian skor tertinggi dengan jumlah item pertanyaan serta dengan jumlah responden. Adapun skor tertinggi yang dipakai dalam analisis kuantitatif ini yaitu 5, karena gradasi yang digunakan sebagai berikut :

5 untuk kategori sangat setuju

4 untuk kategori setuju

3 untuk kategori kurang setuju

2 untuk kategori tidak setuju

1 untuk kategori sangat tidak setuju 
Sedangkan jumlah item pertanyaan yang disebarkan sebagai tahap penguraian lebih jauh dari konsep pelaksanaan Pelayanan Kesehatan Ibu Anak yaitu 8 pertanyaan, untuk 78 responden, jadi perkaliannya adalah $8 \times 5$ $\mathrm{x} 78=3120$. Nilai tersebut menjadi acuan atau pembanding jumlah skor item pernyataan. Jumlah skor item pernyataan tersebut dari item 1 sampai dengan 10 yaitu: $341+354+344+355+379+358+323+342=$ 2796 Jadi berdasarkan data tersebut dapat diketahui bahwa pelaksanaan Pelayanan Kesehatan Ibu Anak yaitu: 2796 : $3120=$ $89,61 \%$.

\section{Analisis Seluruh Item Pertanyaan Variabel Terikat (Peningkatan Kesehatan Masyarakat).}

Untuk lebih mengetahui faktor-faktor pengukuran peningkatan Kesehatan secara keseluruhan dapat dihitung dengan mengalikan skor tertinggi dengan jumlah item pertanyaan serta dengan jumlah responden. Adapun skor tertinggi yang dipakai dalam analisis kuantitatif ini yaitu 5, karena gradasi yang digunakan sebagai berikut:

5 untuk kategori sangat setuju

4 untuk kategori setuju

3 untuk kategori kurang setuju

2 untuk kategori tidak setuju

1 untuk kategori sangat tidak setuju
Sedangkan jumlah item pertanyaan yang disebarkan sebagai tahap penguraian lebih jauh dari karakteristik peningkatan Kesehatan Masyarakat yaitu 10 pertanyaan untuk 78 responden. Jadi perkaliannya adalah 10 x $5 \mathrm{x}$ $78=3900$. Nilai tersebut menjadi acuan atau pembanding jumlah skor item pernyataan. Jumlah skor item pernyataan tersebut dari item 1 sampai dengan 10 yaitu: $361+323+324+314+308+295+349+355+377+$ $327=3378$ Jadi berdasarkan data tersebut dapat diketahui bahwa Kesehatan Masyarakat yaitu: $3378: 3900=86,61 \%$.

\section{Uji Validitas}

Uji Validitas adalah mengkorelasikan skor setiap butir dengan skor total yang merupakan jumlah tiap skor butir, dan syarat minimum untuk dianggap valid yaitu bila $r=$ 0,22 ke atas, berdasarkan data yang terkumpul dari variabel bebas (Pelaksanaan Pelayanan Kesehatan Ibu Anak) dan variabel terikat (Peningkatan Kesehatan Masyarakat) maka terdapat hasil yang ditunjukkan pada tabel lampiran.

Sedangkan untuk mengetahui (a) besaran signifikasi variabel pelaksanaan

(b) Pelayanan Kesehatan Ibu Anak, signifikasi (c) nilai korelasi dilakukan dengan derajat (d) kebebasan $(\mathrm{dk}=\mathrm{n}-2)$ dengan kaidah (e) penilaian : Jika $r$ hitung $>r$ tabel berarti valid dan sebaliknya. Jika instrumen itu valid, maka dilihat kriteria penafsiran sebagaimana terlampir. Adapun hasil uji validitas untuk variabel bebas (Pelayanan Kesehatan Ibu Anak) adalah sebagai berikut:

Tabel 4.

Hasil Uji Validitas Pelayanan Kesehatan Ibu Dan Anak

\begin{tabular}{ccccc}
\hline Korelasi antara & $\begin{array}{c}\text { Nilai Korelasi } \\
(\mathrm{r})\end{array}$ & $\begin{array}{c}\text { Nilai } \mathrm{r} \text { tabel } \\
(\mathrm{n}=78, \alpha=5 \%)\end{array}$ & Keterangan & Kesimpulan \\
\hline Item No. 1 & 0.704874 & & $\begin{array}{c}\mathrm{r} \text { Positif } \\
\mathrm{r} \text { hitung }>\mathrm{r} \text { tabel } \\
\mathrm{r} \text { Positif }\end{array}$ & Valid \\
$\begin{array}{c}\text { dengan Total } \\
\text { Item No. } 2\end{array}$ & 0.445792 & & $\begin{array}{c}\mathrm{r} \text { hitung }>\mathrm{r} \text { tabel } \\
\mathrm{r} \text { Positif }\end{array}$ & Valid \\
$\begin{array}{c}\text { dengan Total } \\
\text { Item No. } 3\end{array}$ & 0.367532 & 0,22 & $\begin{array}{c}\mathrm{r} \text { hitung }>\mathrm{r} \text { tabel } \\
\mathrm{r} \text { Positif }\end{array}$ & Valid \\
dengan Total & & & $\mathrm{r}$ hitung $>\mathrm{r}$ tabel & Valid \\
Item No. 4 & 0.331934 & &
\end{tabular}


Item No. 5

0.519434

dengan Total

Item No. 6

0.571725

dengan Total

Item No. 7

dengan Total

0.554156

Item No. 8

0.299676

dengan Total

Dari hasil Uji Validitas instrumen di atas, terlihat bahwa semua instrumen valid dan Signifikan. Kemudian butir semua instrumen Valid dapat dipergunakan untuk uji

$\begin{array}{cc}r \text { Positif } & \text { Valid } \\ r \text { hitung }>r \text { tabel } & \\ r \text { Positif } & \text { Valid } \\ r \text { hitung }>r \text { tabel } & \\ r \text { Positif } & \text { Valid } \\ r \text { hitung }>r \text { tabel } & \\ r \text { Positif } & \text { Valid } \\ r \text { hitung }>r \text { tabel } & \end{array}$

selanjutnya. Sedangkan uji validasi variabel terikat (peningkatan Kesehatan Masyarakat) adalah sebagai berikut:

Tabel 5

Hasil Uji Validitas Peningkatan Kesehatan Masyarakat Pegawai

\begin{tabular}{|c|c|c|c|c|}
\hline $\begin{array}{c}\text { Korelasi } \\
\text { antara }\end{array}$ & $\begin{array}{l}\text { Nilai Korelasi } \\
\text { (r) }\end{array}$ & $\begin{array}{l}\text { Nilai } r \text { tabel } \\
(\mathrm{n}=78, \alpha=5 \%)\end{array}$ & Keterangan & Kesimpulan \\
\hline $\begin{array}{c}\text { Item No. } 1 \\
\text { dengan Total }\end{array}$ & 0.591036 & & $\begin{array}{c}r \text { Positif } \\
r \text { hitung }>r \text { tabel }\end{array}$ & Valid \\
\hline $\begin{array}{c}\text { Item No. } 2 \\
\text { dengan Total }\end{array}$ & 0.553974 & & $\begin{array}{c}r \text { Positif } \\
\text { r hitung }>r \text { tabel }\end{array}$ & Valid \\
\hline $\begin{array}{c}\text { Item No. } 3 \\
\text { dengan Total }\end{array}$ & 0.37577 & & $\begin{array}{c}r \text { Positif } \\
\text { r hitung }>r \text { tabel }\end{array}$ & Valid \\
\hline $\begin{array}{c}\text { Item No. } 4 \\
\text { dengan Total }\end{array}$ & 0.352259 & & $\begin{array}{c}r \text { Positif } \\
\text { r hitung }>r \text { tabel }\end{array}$ & Valid \\
\hline Item No. 5 & 0.445443 & & $\begin{array}{l}\text { r Positif } \\
r\end{array}$ & Valid \\
\hline $\begin{array}{l}\text { Item No. } 6 \\
\text { dengan Total }\end{array}$ & 0.429546 & 0,22 & $\begin{array}{c}r \text { Positif } \\
r \text { hitung }>r \text { tabel }\end{array}$ & Valid \\
\hline $\begin{array}{c}\text { Item No. } 7 \\
\text { dengan Total }\end{array}$ & 0.744368 & & $\begin{array}{c}r \text { Positif } \\
\text { r hitung }>r \text { tabel }\end{array}$ & Valid \\
\hline $\begin{array}{c}\text { Item No. } 8 \\
\text { dengan Total }\end{array}$ & 0.303963 & & $\begin{array}{c}r \text { Positif } \\
\text { r hitung }>r \text { tabel }\end{array}$ & Valid \\
\hline $\begin{array}{c}\text { Item No. } 9 \\
\text { dengan Total }\end{array}$ & 0.55984 & & $\begin{array}{c}r \text { Positif } \\
r \text { hitung }>r \text { tabel }\end{array}$ & Valid \\
\hline $\begin{array}{l}\text { Item No. } 10 \\
\text { dengan Total }\end{array}$ & 0.287429 & & $\begin{array}{c}r \text { Positif } \\
r \text { hitung }>r \text { tabel }\end{array}$ & Valid \\
\hline
\end{tabular}

Penafsiran pada tabel di atas, dari hasil Uji Validitas instrumen di atas, terlihat bahwa semua instrumen Valid dan Signifikan. Kemudian butir semua instrumen Valid dapat dipergunakan untuk uji selanjutnya.

\section{Uji Reliabilitas}

Setelah dihitung dengan menggunakan alat bantu microsoft excel diperoleh koefisien korelasi variabel bebas (Pelayanan Kesehatan Ibu Anak) sebesar 0,218 dan variabel terikat (Peningkatan Kesehatan Masyarakat) sebesar 0,324 koefisien-koefisien korelasi tersebut selanjutnya dimasukkan dalam rumus Spearman Brown.

\section{Reliabilitas Instrumen Pelayanan Kesehatan Ibu Anak}


$R=\frac{2 r}{1+r}$

$=\frac{2(0,218)}{1+0,218}$

$=0,36$

\section{Reliabilitas Instrumen Peningkatan Kesehatan Masyarakat}

$R=\frac{2 r}{1+r}$

$=\frac{2(0,324)}{1+0,324}$

$=0,49$

Hasil rangkuman dari perhitungan tersebut di atas, dapat dilihat dalam tabel berikut ini:

Tabel: 6

Rangkuman Hasil Perhitungan Reliabilitas Instrumen

\begin{tabular}{lcccc}
\hline \multicolumn{1}{c}{ Variabel } & $\begin{array}{c}\text { Koefisien } \\
\text { Korelasi }(\mathbf{r})\end{array}$ & $\begin{array}{c}\text { Harga } \\
(\mathbf{r})\end{array}$ & r tabel & Hasil \\
\hline Pelayanan Kesehatan Ibu Anak & 0,218 & 0,36 & 0,22 & Reliabel \\
Peningkatan Kesehatan Masyarakat & 0,324 & 0,49 & 0,22 & Reliabel
\end{tabular}

Dari tabel di atas, terlihat bahwa semua instrumen penulisan reliabel dan dapat diandalkan.

\section{Analisa Korelasi Antara Pelayanan \\ Kesehatan Ibu Anak Terhadap \\ Peningkatan Kesehatan Masyarakat}

Penulis menggunakan analisis korelari

Produk Moment sebagai rumusnya, Uji

Signifikansi, Koefisien Determinasi dan analisis persamaan regresi sederhana sehingga dari pengaruh yang diperoleh dapat menaksir variabel $\mathrm{Y}$ apabila variabel $\mathrm{X}$ diketahui. Berdasarkan data di atas, penulis memperoleh dua variabel yang dapat di ukur yaitu: Variabel $\mathrm{X}=$ Pelayanan Kesehatan Ibu Anak, dan Variabel $\mathrm{Y}=$ Peningkatan Kesehatan Masyarakat

\section{Koefisien Korelasi}

$r_{x y}=\frac{\sum X Y}{\sqrt{\left(\sum X^{2}\right)\left(\sum Y^{2}\right)}}$
Berdasarkan rumus tersebut diperoleh nilainilai sebagai berikut :

$$
\begin{aligned}
\mathrm{n} & =78 \\
\Sigma \mathrm{X} & =2802 \\
\Sigma \mathrm{Y} & =3364 \\
\Sigma \mathrm{XY} & =121282 \\
\Sigma \mathrm{X}^{2} & =101062 \\
\Sigma \mathrm{Y}^{2} & =145832 \\
r_{x y} & =\frac{\sum X Y}{\sqrt{\left(\sum X^{2}\right)\left(\sum Y^{2}\right)}} \\
r_{x y}= & \frac{121282}{\sqrt{(101062)(145832)}} \\
r_{x y}= & 0,999
\end{aligned}
$$

Berdasarkan perhitungan di atas, koefisien korelasi (r) antara Pelayanan Kesehatan Ibu Anak adalah sebesar 0,999 atau $99,9 \%$, berdasarkan tabel interpretasi koefisien korelasi, dapat diketahui bahwa hubungan antara Pelayanan Kesehatan Ibu dan Anak terhadap Peningkatan Kesehatan Masyarakat terbukti 
adanya hubungan yang positif dan sangat kuat.

\section{Uji Signifikasi}

$$
\begin{aligned}
& t=\frac{r s \sqrt{n-2}}{\sqrt{1-r^{2}}} \\
& t=\frac{0,999 \sqrt{78-2}}{\sqrt{1-0,999^{2}}} \\
& t=\frac{8,71}{0,045} \\
& t=193,5
\end{aligned}
$$

Harga $\mathrm{t}$ hitung tersebut selanjutnya dibandingkan dengan harga $t$ hitung tersebut selanjutnya dibandingkan dengan harga $t$ tabel. Berdasarkan tabel distribusi $\mathrm{t}$ menurut Sugiyono, untuk $\mathrm{dk}=78-2=76$ dengan taraf kesalahan $0,05 \%$ adalah 1,66 Hal ini dapat digambarkan sebagai berikut

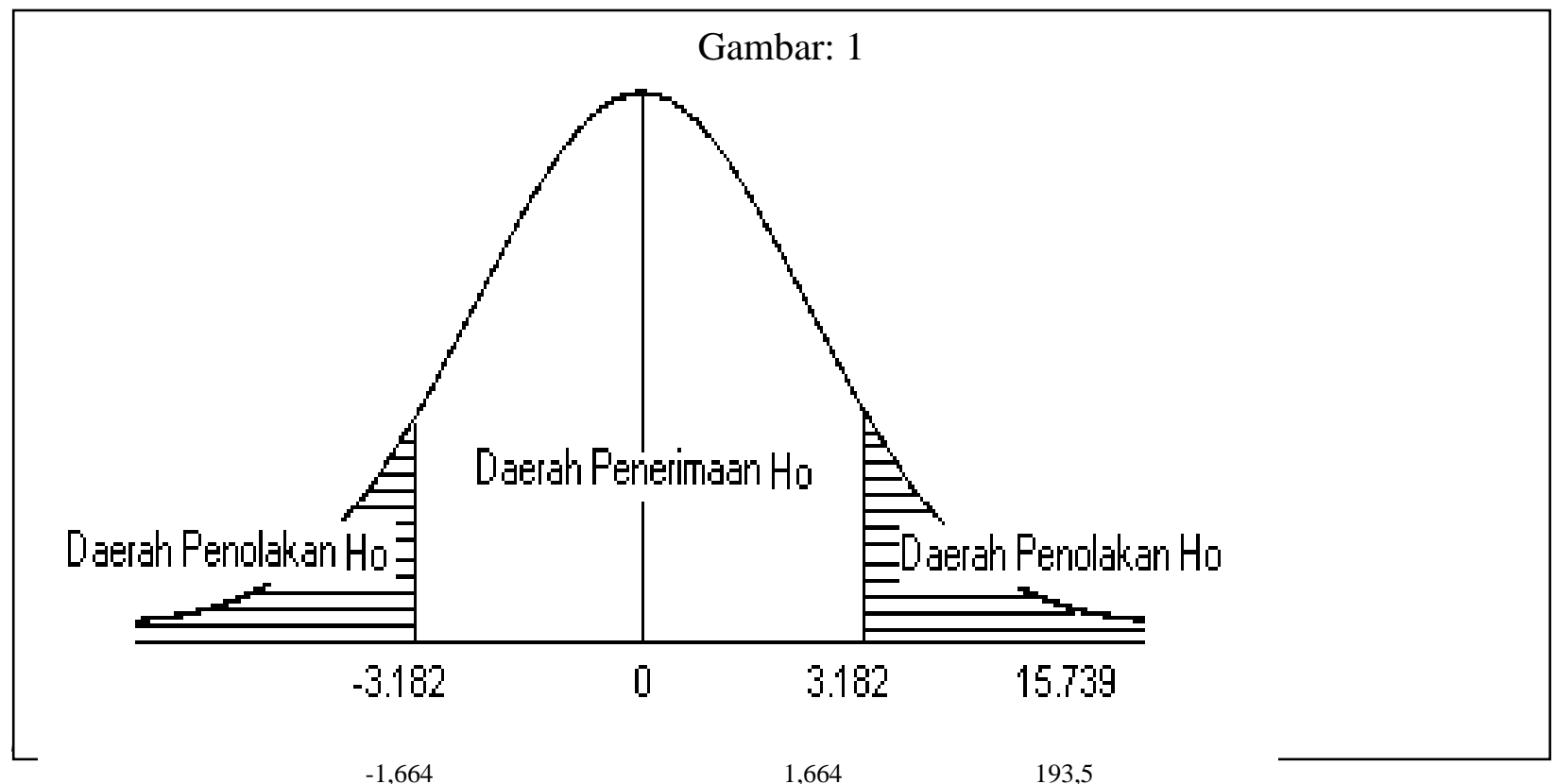

\section{Koefisien Penentu (Determinasi)}

$$
\begin{aligned}
& K D=r^{2} X 100 \% \\
& K D=(0,999)^{2} X 100 \% \\
& K D=99,8 \%
\end{aligned}
$$

Dari perhitungan koefisien penentu/koefisien diterima (KD) sebesar 99,8\% berarti pelaksanaan Pelayanan Kesehatan Ibu dan Anak memberi kontribusi 99,8\% terhadap Peningkatan Kesehatan Masyarakat, sedangkan sisanya sebesar $0,2 \%$ merupakan faktor lain yang tidak ditinjau dalam penulisan ini yang ikut serta mempengaruhi Peningkatan Kesehatan
Masyarakat yang perlu dilakukan penulisan lebih lanjut.

\section{Analisa Persamaan Regresi Sederhana}

Persamaam regresi ini digunakan untuk melakukan prediksi seberapa tinggi nilai variabel bebas (pelaksanaan Pelayanan Kesehatan Ibu Anak ) apabila nilai variabel terikat (Peningkatan Kesehatan Masyarakat) dimanipulasi (diubah-ubah). Secara umum persamaan regresi sederhana (dengan satu prediktor) dapat dirumuskan sebagai berikut: 
$\mathbf{Y}=\mathbf{a}+\mathbf{b} \mathbf{X}$

Dengan diketahui:

$$
\begin{array}{ll}
\mathrm{n} & =78 \\
\Sigma \mathrm{X} & =2802 \\
\Sigma \mathrm{Y} & =3364 \\
\Sigma \mathrm{XY} & =121282 \\
\Sigma \mathrm{X}^{2} & =101062 \\
\Sigma \mathrm{Y}^{2} & =145832
\end{array}
$$

Menentukan harga a:

$$
\begin{aligned}
& a=\frac{\left(\sum Y\right)\left(\sum X^{2}\right)-\left(\sum X\right)\left(\sum X Y\right)}{n \sum X^{2}-\left(\sum X\right)^{2}} \\
& a=\frac{((3364)(101062))-((2802)(121282))}{78(101062)-(2802)^{2}} \\
& a=\frac{339972568-339832164}{7882836-7851204} \\
& a=\frac{140404}{31632} \\
& a=4,43
\end{aligned}
$$

Menentukan harga $b$.

$$
b=\frac{n \sum X Y-\left(\sum X\right)\left(\sum Y\right)}{n \sum X^{2}-\left(\sum X\right)^{2}}
$$$$
b=\frac{78(121282)-(2802)(3364)}{78(101062)-(2802)^{2}}
$$$$
b=\frac{9459996-9425928}{7882836-7851205}=
$$

$b=\frac{34068}{31632}$

$b=1,07$

Berdasarkan harga a dan b melalui perhitungan di atas, maka persamaan regresi Pelaksanaan Pelayanan Kesehatan Ibu Anak dan Peningkatan Kesehatan Masyarakat adalah sebagai berikut:

$\hat{\mathrm{Y}}=4,43+1,07 \mathrm{X}$.

Persamaan regresi yang telah ditentukan tersebut dapat digunakan untuk melakukan prediksi (ramalan) berapa nilai dalam variabel terikat akan terjadi bila nilai dalam variabel bebas ditetapkan. Hal ini berarti bila kualitas Pelaksanaan Pelayanan Kesehatan Ibu Anak di tingkatkan sampai nilai optimal sesuai dengan skor ideal instrumen yaitu $5 \times 78=390$ maka nilai peningkatan Kesehatan Masyarakat dapat dilihat sebagai berikut:

$\hat{\mathrm{Y}}=4,43+1,07(390)=421,73$

Jadi diperkirakan nilai Peningkatan Kesehatan Masyarakat menjadi 421,73 Jika nilai Pelayanan Kesehatan Ibu dan Anak dinaikkan menjadi 390 Sehingga dari persamaan di atas dapat diartikan, bahwa bila Peningkatan Kesehatan Masyarakat agar bertambah 1, maka nilai rata-rata pelayanan Kesehatan Ibu dan Anak harus dinaikkan sebesar 4,43.

\section{KESIMPULAN DAN SARAN}

Berdasarkan analaisis bahwa pengaruh pelayanan Kesehatan Ibu dan Anak sebesar 89,61\%; peningkatan kesehatan masyarakat mencapai persentase sebesar $86,61 \%$. Koefisien korelasi antar pelayanan Kesehatan Ibu Anak dengan peningkatan kesehatan masyarakat diperoleh nilai korelasi (r) sebesar 0,999 Sedangkan $t$ hitung sebesar $193,5>\mathrm{t}$ tabel sebesar 1,66, ini berarti terdapat hubungan yang positif dan signifikan antara pelayanan kesehatan Ibu Anak terhadap peningkatan kesehatan masyarakat. Sedangkan Koefisien determinasi diperoleh sebesar 99,8\% ini menandakan bahwa pelayanan Kesehatan Ibu Anak sebagai salah satu faktor yang mempengaruhi tingkat kesehatan masyarakat sebesar 99,8\%. Kemudian sisanya yaitu $0,2 \%$ berarti ada faktor lain yang turut mempengaruhi peningkatan kesehatan masyarakat.

Persamaan regresi Pelaksanaan Pelayanan Kesehatan Ibu dan Anak dan Peningkatan Kesehatan Masyarakat Pegawai yaitu $\hat{\mathrm{Y}}=4,43+1,07 \mathrm{X}$. Selanjutnya persamaan regresi tersebut dapat digunakan untuk melakukan prediksi (ramalan) berapa nilai dalam variabel terikat (Peningkatan Kesehatan Masyarakat) akan terjadi bila nilai dalam variabel bebas (Pelaksanaan Pelayanan Kesehatan Ibu Anak) ditetapkan. 
Berdasarkan hasil analisis dan kesimpulan di atas, maka dikemukakan saran dalam pelayanan Kesehatan Ibu dan Anak, disarankan agar Pusat Kesehatan Masyarakat Kibin, Kecamatan Kibin Kabupaten Serang berdasarkan asas-asas pelayanan. Untuk meningkatan kesehatan masyarakat,

\section{DAFTAR PUSTAKA}

\section{Buku}

Almatsier, Sunita, 2009 Prinsip Dasar Ilmu Gizi, Gramedia Pustaka Utama Jakarta; Depdagri dan Otonomi daerah serta Departemen Keuangan, 2000 Manajemen Pelayan Prima, Jakarta

Hasibuan, H.Malayu S.P., 2001 Manajemen Sumber Daya Manusia Edisi Revisi, Bumi Aksara Jakarta.

Handoko, T.Hani, 2003 Manajemen Edisi 2, BPFE, Universitas Gajah Mada, Yogyakarta

Hernawati, Irna,2008 Pedoman Respon Cepat Penanggulangan Gizi Buruk, Departemen Kaesehatan RI Dirjen Bina Kesehatan Kesehatan Masyarakat Direktorat Bina Gizi Masyarakat, Jakarta

H. A. S. Moenir, 2008 Manajemen Pelayanan Umum di Indonesia, Bumi Aksara, Jakarta

Kristiadi, 1996 Manajemen Pelayanan Prima, Bumi Aksara, Jakarta

Lembaga Administrasi Negara, 2002 Manajemen Pelayanan Publik, Jakarta

Mangkunegara, AA.Prabu, 2009 Manajemen Sumber Daya Manusia Perusahaan, Remaja Rosdakarya Offset Bandung disarankan agar dapat meningkatkan pelayanan Kesehatan Ibu dan Anak dapat berlaku adil sesuai peraturan yang berlaku. Dapat memperhatikan kebutuhan-kebutuhan dan harapan masyarakat, serta memperhatikan hak dan kewajiban dalam melaksanakan pelayanan.

Notoatmodjo, Soekijo, 2003 Ilmu Kesehatan Masyarakat Prinsip-Prinsip Dasar, Remaja Rosdakarya Offset Bandung

Nasir, 2004 Metode Penulisan Sosial, Alfabeta, Jakarta

Pamudji, 1997 Manajemen Pelayanan Prima, Remaja Rosdakarya Offset Bandung

Silalahi, Ulber: 2002, Pemahaman Praktis Asas-Asas Manajemen, CV.Mandar Maju, Jakarta.

Simbolon, Maringan Masry, 2004 Dasardasar Administrasi dan Manajemen, Ghalia Indonesia Jakarta

Sastrohadiwiryo, B. Siswanto, 2005 Manajemen Tenaga Kerja Indonesia Pendekatan administrasi dan Operasional, Bumi Aksara Jakarta

Sugiyono : 2007, Metode Penulisan Kuantitatif Kualitatif Dan $R \& D$, Alfabeta, Jakarta

Sedarmayanti, 2009 Manajemen Sumber Daya Manusia Reformasi Birokrasi dan Manajemen Kepegawaian Republik Indonesia, Bumi Aksara, Jakarta

Soekamto, Soerjono, 2009, Sosiologi Suatu Pengantar, Raja Grafindo Persada, Jakarta; 
Tjiptono, Fandy, 2008 Service Manajemen Mewujudkan Layanan Prima, Andi Yogyakarta;

Trigono, 1997 Manajemen Pelayanan Publik, Alfabeta, Jakarta;

Susanto, 2002 Manajemen Pelayanan Umum, Alfabeta, Jakarta

Siagian, Sondang P, 2009 Manajemen Sumber Daya Manusia, Bumi Aksara Jakarta

Usman, Husaini, 2009 Metode Penulisan Sosial, PT.Bumi Aksara, Jakarta

Umar, 2002 Metode Penulisan Sosial, Alfabeta, Jakarta

Winarsih, Atik Septi \& Ratminto, 2008 Manajemen Pelayanan Pengembangan Model Konseptual, Penerapan Citizen's Charter dan Standar Pelayanan Minimal, Pustaka Pelajar, Jakarta

Zainun, Buchari, 2004 Administrasi \& Manajemen Sumber Daya Manusia Pemerintah Negara Indonesia, Alfabeta, Jakarta.

\section{Dokumen}

Undang Undang RI, nomor: 23 tahun 1992 Tentang Kesehatan Masyarakat, Jakarta

Undang Undang RI, nomor: 25 tahun 2009, Tentang Pelayanan Publik

Undang Undang RI, nomor: 9 tahun 1960, Tentang Undang Undang Pokok Kesehatan
Dep. Kes. RI, 1997 Pedoman Pelatihan Program Makanan Tambahan Anak Sekolah (PMT-AS) Tingkat Desa / Kelurahan, Forum Komunikasi, Jakarta

Departemen Kesehatan RI, 1998 Tuntutan Praktis Bagi Tenaga Gizi Puskesmas, Bekalku Membina Keluarga Sadar Gizi (KADARZI), Jakarta

Permenkes RI, nomor: 74/Menkes/Per/VII/2008, Tentang Standar Pelayanan Minimal Bidang Kesehatan di Kabupaten/Kota

Surat Keputusan Menkes RI, nomor: 99/Menkes/SK/III/1982, Sistem Kesehatan Nasional

SE.Kementrian PAN, nomor: 81/1993, Tentang Kualitas Pelayanan, Kementrian Pendayagunaan Aparatur Negara:Jakarta

\section{Dokumen Lain}

Internet;

http://arisbambang.wordpress.com/kesehatan/

http://id.shvoong.com/medicine-andhealth/medicine-history/2091011.

http://almawaddah.wordpress.com/2009/02/0 7/cara-mendeteksi-gizi-buruk-padabalital.

http://ajago.blogspot.com/2007/11/pengantar -kesehatan-masyarakat.html

http://environmentalsanitation.wordpress.com /category/pengertian-kesehatanmasyarakat/, December 27, 2008, Archive for the 'Pengertian Kesehatan Masyarakat' Category; 